\title{
Lightning Stroke Currents
}

$\mathrm{R}$ ECEN'T laboratory researches on impulsive rushes of electricity produced by high-voltage discharges of condensers have proved of great value by leading to improvements in the methods used in protecting buildings and overhead wires from damage by lightning strokes. The discharge in the laboratory is very similar to the lightning stroke in Nature. The sound produced, although the are is only a few feet long, is uncomfortable and often painful to the ear. Anyone taken unawares by a laboratory discharge occurring a few feet away might be seriously affected by the blinding light and the deafening noise produced.

In a paper read at the Pacific Coast Convention of the American Institute of Electrical Engineers, Seattle, Mr. P. L. Bellaschi gives definite and interesting information about lightning strokes. Statistics prove that most of them are single discharges. The number of multiple discharge strokes is about 20 per cent, and the number of oscillations is very seldom greater than four. Field observations show that multiple discharges sometimes strike the ground at appreciable distances apart. Hundreds of cases are known where bronze conductors, used in telephone circuits, which are about 2 square millimetres in crosssection have been fused by lightning. A case has been reported where lightning has vaporised a $3 \cdot 34 \mathrm{sq}$. $\mathrm{mm}$. copper conductor. Several thousands of wood poles used for telegraphs and protected by 21 sq. mm. steel wires connected to the earth have been kept under observation for several years. None of the wires was found fused and none of the poles was damaged, although previously to being protected they were often found shattered.

Assuming that an ordinary lightning stroke fuses a 2 sq. mm. bronze conductor, and that it consists of a single discharge, then on the basis of a duration of 40 microseconds, the maximum value of the current produced by the stroke would be of the order of 100,000 amperes. On the basis of a 100 millionths of a second duration, the current would be of the order of 65,000 amperes. The data available show that currents as high as 200,000 amperes would be very rare.

Photographs are shown of copper tubes that have been crushed inwards by lightning discharges. In one case a hollow copper rod $1.47 \mathrm{~cm}$. inside diameter and $6 \cdot 675 \mathrm{~mm}$. thick was crushed by lightning. From the incipient fusion shown in several places, the rod was obviously raised to a high temperature. The crushing force was calculated to be $400 \mathrm{lb}$. per sq. inch of tube surface. An oscillatory discharge would considerably increase this crushing force.

Lightning strokes to guy wires have blasted the rock, cement, etc., in which the wires were embedded. The shattering of poles and trees is a familiar occurrence. Parts of shattered objects have been thrown distances of more than a hundred feet. Metal pipes have been cracked and broken open by lightning. Experiments are quoted which show that the diamoter of the lightning stroke channel generally lies between one and two centimetres.

\section{Aluminium in Food}

$S^{\mathrm{T}}$ ATEMENTS appear from time to time incriminating the use of aluminium cooking utensils as dangerous to health, the small amounts of the metal that are dissolved by the food being considered responsible for the occurrence of various human ailments. As often as such allegations have been made they have been denied, and the question is not yet settled. There is no doubt that the ingestion of relatively large amounts of aluminium produces toxic symptoms, but it is not so simple to prove the toxicity to human beings of the minute amounts which are non-toxic to animals. In any event, knowledge of the amounts of the metal likely to be met with in cooked foods and of the amounts producing symptoms in animals is a prerequisite to a discussion on the subject. Such information is provided in a recent review by Monier-Williams*.

Alum itself has in the past been used as the acid ingredient of commercial baking powder and is still so used in some countries: bread made with such

- Ministry of Health. Reports on Public Health and Medical Subjects, No. 78 : Aluminium in Food. By Dr. G. W. Monier-Williams. Pp. 34. (London: H.M. Stationery Office, 1935.) $9 d$. net. a baking powder may contain as much as 0.05 per cent of aluminium, or 500 parts in a million. The amount found in foodstuffs is much less and a large part of that found in plants is probably adventitious in origin, due to contamination with soil and dust. Probably the amount consumed daily with food is of the order of $5-10$ parts, or less, per million. In animal organs the quantities are of the order of 1-2 parts in a million.

The accurate determination of aluminium in food and biological material is a difficult matter. MonierWilliams describes a method in which 8-hydroxyquinoline is used as a precipitating agent for aluminium. It has the advantage that the compound with aluminium contains only 5.9 per cent aluminium, so that small amounts can be determined with great accuracy; the precipitate can be weighed or titrated with bromine.

The amount of aluminium taken up by food during cooking varies greatly with its nature, especially its acidity, and the conditions of cooking as well as with the particular utensils used: the purer the metal employed in the latter the more resistant is it to corrosion. Probably less than 10 parts in a million 
is usually the amount occurring in food cooked in aluminium vessels. It appears that a considerable proportion of the metal taken into the stomach is soluble, but the actual amount dissolved varies greatly with the circumstances. Only minute amounts, however, appear to be absorbed into the body, from determinations of the quantity in the blood, tissues or urine. The presence of relatively large amounts of the metal in the digestive tract may interfere with the digestive processes, alum especially producing gastro-intestinal irritation and loss of appetite in both animals and man.

Neither these experiments nor those which show the harmlessness of the ingestion of small amounts of aluminium are necessarily conclusive, since it is possible that there may be individuals who are susceptible to even such small doses of the metal as may be derived from aluminium utensils. MonierWilliams concludes that there is no convincing evidence that these small amounts have a harmful effect upon the ordinary consumer, but that it is undesirable to admit the entry of aluminium into food in the relatively large amounts in which it may be employed as a constituent of baking powders or self-raising flour.

\section{Phytoplankton and Herrings*}

$\mathrm{T}$ HE concentration of phytoplankton organisms at times in dense patches in various parts of the sea is a phenomenon, which was recognised by early observers (see also Nature, Dec. 7, p.897). These brownish or greenish patches in the North Sea, usually formed of the diatoms Rhizosolenia or the colonial flagellate Phoocystis and accompanied by a slime which clogs the nets are well known to the fishermen, who call such discoloured water 'stinking water', 'weedy water', 'Dutchman's baccy juice', etc., regarding it as a bad sign for the fishing. The present authors analyse the herring fishery of the southern North Sea together with the occurrence of these phytoplankton patches, the object of the work being "to give an account of our knowledge of the distribution and movement of any dense phytoplankton concentra. tions in the southern North Sea from 1921 to 1932 (excepting years 1928 and 1929) at such times as might affect the herring fishing, and by examining the official reports and statistics of the fisheries from year to year to see whether or not the existence of these patches, either on the fishing grounds 'themselves, or lying in the path of incoming shoals of fish, can be regarded as a probable cause of some of the fluctuations in the herring landings over this period."

It has been found again and again that where large zones of phytoplankton occur the herrings avoid them, sometimes making extensive detours rather than penetrate them, and that these patches form definite barriers to the oncoming shoals.

At the time of the great herring shoaling in the southern North Sea, Rhizosolenia styliformis and Phoeocystis are the outstanding features of the plankton in this area, and when the fish have been plentiful and the fishing above the average, no instance is found of a concentration of plankton in such a position where it might be held to have

* Ministry of Agriculture and Fisheries. Fishery Investigations, series 2, vol. 14, No. 2, 1934: Phytoplankton and the Herring. Part 1: 1921 to 1932. By R. E. Savage and Prof. A. C. Hardy. Pp. 73. (London: H.M. Stationery Office, 1935.) 38. $6 \bar{d}$. net. an influence on the fishery, whereas on each occasion when the fishery has been below the average and the decrease cannot be attributed to weather or economic conditions, phytoplanktonic concentrations occurred. Four factors are cited as possibly influencing the fishery-the effect of the moon, year classes, gales and economic conditions; to these are now added the very probable and now almost certain factor of influence of phytoplankton.

The authors note further that since the present paper was being prepared for press another autumn season has come round, 1933, and this brings with it such striking evidence in favour of the phytoplankton hypothesis that they feel justified in regarding this as not only possible but even highly probable.

\section{Educational Topics and Events}

Cambridge.-N. G. Hentley, of St. John's College, has been appointed to the Benn W. Levy research studentship in biochemistry.

At Queens' College, Sir C. J. H. Thomas, Permanent Secretary of the Ministry of Agriculture and Fisheries, has been elected into an honorary fellowship.

Mr. C. W. Gilbert, of Christ's College, has been elected into a research fellowship at Jesus College.

An election to the Pinsent-Darwin studentship in mental pathology will be made in January 1936. The studentship is of the annual value of not less than $£ 225$, and is tenable for three years. The student must engage in original research into any problem having a bearing on mental defects, diseases or disorders, but may carry on educational or other work concurrently. Applications should be sent before January 1, 1936, to the Secretary, PinsentDarwin Studentship, Psychological Laboratory, Cambridge.

Erections to three Beit fellowships for scientific research will take place on or about July 10, 1936. A fellowship is of the annual value of $£ 240$, and is tenable for two years at the Imperial College of Science and Technology, South Kensington, London, S.W.7. Candidates must be less than twenty-five years of age. Further information can be obtained from the Rector of the College.

The thirty-sixth annual meeting of the Science Masters' Association will be held in the Chemistry Department of the Imperial College of Science and Technology, South Kensington, London, S.W.7, on January 1-4, under the presidency of Sir William Bragg. The following lectures will be delivered during the meeting : Sir William Bragg, "School Science after School" (presidential address); Prof. J. C. Philip, "Chemical Fogs"; Prof. J. W. Munro, "Recent Advances in Economic Entomology"; Dr. H. J. T. Ellingham, "Primary Cells: their Nature and Action"; Dr. John Taylor, "The Doctor as Detective". There will also be a lecture-demonstration of biological films by H. R. Hewer. Among the discussions to be held is one on "Geometrical Opticsespecially Sign Conventions" and another on "School Certificate Biology Syllabus". Further particulars can be obtained from the Annual Meeting Secretary, The Square, Repton, Derby. 